ПРИЛОЗИ, Одделение за природно-математички и биотехнички науки, МАНУ, том 38, бр. 1, стр. 101-104 (2017)

CONTRIBUTIONS, Section of Natural, Mathematical and Biotechnical Sciences, MASA, Vol. 38, No. 1, pp. 101-104 (2017)

Received: February 15, 2017

ISSN 1857-9027

Accepted: April 7, 2017

e-ISSN 1857-9949

UDC: $811.163 .3 ’ 373.45: 54$

DOI:10.20903/csnmbs.masa.2017.38.1.105

Short communication

\title{
THE LANGUAGE REQUIRES RESEARCH
}

\author{
Zuzanna Topolińska \\ Research Center for Areal Linguistics, Macedonian Academy of Sciences and Arts, \\ Skopje, Republic of Macedonia \\ e-mail: zuzana@manu.edu.mk
}

This paper focuses on some of the more serious issues faced by the Macedonian language. One of them, is certainly the lack of a serious scholarly Macedonian grammar that shall be up-to-date with the development of the language which, like all other languages, is a complex adaptive system. Consequently, there is a lack of a historical grammar and modern language grammar. Another serious issue identified is the unfinished work on the Macedonian dialect dictionary and, in general, the inadequate care for dialectology. In the first part of the paper, we highlight the link between the need for greater linguistic research and the fact that this volume of the journal Contributions is dedicated to the marking of the 80th birthday of academician Bojan Šoptrajanov, our "honorary linguist".

Key words: Macedonian language, history of Macedonian language research, dialectology, historical grammar

Having the opportunity to take part in the celebration of the $80^{\text {th }}$ birthday of academician Bojan Šoptrajanov, I would like to take advantage of it to also discuss the issues stated in the title of this paper.

Years ago, right after the establishment of the Research Center for Areal Linguistics at MASA (Macedonian Academy of Sciences and Arts), we the "centrists" bestowed the title of an honorary linguist to academician Bojan Šoptrajanov because we were impressed by his understanding of the tasks of linguistics, his real interest in the matters of our language, his publications dedicated to the scientific and professional terminology of his discipline chemistry [1-10], as well as his frequent attendance and active participation in our linguistic events.

However, regretfully, this dedication to his language is not a typical attitude either for most Macedonians, or for his colleagues at the University or at MASA.

\section{RESEARCH IS REQUIRED}

On one occasion, when I was trying to explain the pressing need to publish a contemporary grammar of the Macedonian language, I heard a colleague commenting: "Grammar! We already have a grammar! I studied grammar..."

Macedonians, or rather Macedonian intellectuals, usually share a conviction that the established structure of the standard language, fixed down over 70 years ago, is a heritage that we need to nurture and to preserve its purity and inviolability. It never occurs to them that language is a living dynamic structure, with the best proof of the success of its standardization is the fact that this very same structure has shown to be resilient and capable of further development. The language is capable of evolving and adapting to the dynamic world which we live in, while the task of the linguists is to document and interpret the new phenomena and incorporate them in the new editions of the Macedonian Grammar... That is why, when I received the invitation to contribute to the volume dedicated to our honoree, I saw it as an opportunity to explain to our readers the extent to which the Macedonian linguistic library is impoverished and outdated.

\section{HISTORICAL BACKGROUND}

The primary scholarly grammar of the Macedonian language is the authorial monograph by 
Blaže Koneski [11], which has last been revised more than 40 years ago. To reiterate: an authorial monograph, an original work written by a genius poet and a linguist with a rarely seen intuition. It is a work that lends itself to new discoveries at every reading, while at the same time brings back memories of the many times when I came to Blaže with linguistic inquiries only for him to refer me to his Grammar where he had already resolved the issue in question. However, this is not a grammar intended for work with students, let alone younger children, because much of the information is implicitly incorporated in the text of the book. On top of that, during the past 40 years our world has undergone rapid change, intensive development and transformations, while linguistic theory has been upgraded and new theories have been developed bringing new interpretations. Parallel to this, Macedonian standard language has also been evolving, constantly being enriched and adapting to the changes in the society it lives and serves to. The language as it is, represents a so-called "complex adaptive system" a working concept utilized by many exact sciences, one of which is linguistics.

The foundations of Macedonian linguistics during the early years of the young Republic were planned and laid with great thought and care, the process being lead and decisions made by specialists full of passion and love for their language and profession. Yet, in due time as they started to leave us, the awareness about the linguistic priorities got lost along the way. We have a series of monographs dedicated to specific components of grammar, such as syntax, word formation, idiomatic expression, yet they are harmonized neither from a theoretical, nor from a terminological point of view. Though, what is most evident is that their authors are not up to date with the developments in linguistic theory that are happening abroad, nor do they always follow or read each other's work, let alone discuss it publicly. The guidelines for lecturers and proofreaders have not been changed for the past 70 years, failing to take into account the changes that have occurred in the language itself. Our general care for the language which is declared at every possible occasion represents de facto a care for the immutability of the language, in other words it comes down to blocking its natural evolution.

Our Macedonian library lacks works which would illustrate the continued development of the Macedonian language system from its distinction from the old Slavic community until today. Unlike the customary practice in the Slavic northern countries where students are handed both a descriptive grammar and a historical grammar that depicts the history of the evolution of the grammatical system, the university curricula here only includes, unfortunately less and less, dialectology. This is understandable considering the fact that the standardization occurred quite late in the whole Slavic South, while dialects have remained quite alive and vibrant to this very day, containing the overall information about the pre-standard, mostly oral history of the language. Still, this aspect of dialectology as a linguistic branch of science is not sufficiently evaluated. In the work of B. Vidoeski [12-16], the Macedonian dialect complex is covered in its entirety and its evolution is presented along the main lines with a special focus on the western dialect as the basis for standardization. Yet, most readers, predominantly student readers, do not comprehend Vidoeski's works as a veritable history of the Macedonian language, while the existing studies on the history of the language by B. Koneski [17] or by P. Ilievski [18] only concern the so-called external history of the language, its contact with other languages, its presence in written documents, its social status, etc. The only exception (initiated by an outside scholar, Shevelov who was the driving force behind the series!) is the "Historical Phonology" by Koneski [19], which has recently been published in Macedonian to the satisfaction of all of us.

It is regretful that all the preparations for the development of a Macedonian dialect atlas which Vidoeski almost saw through to the end [15] (questionnaire with a rounded network of reference points, completed exploration, drafted demographic descriptions of the villages) were shelved after his death and the passing of Dr. Ubavka Gajdova. Even the card index is still to be digitalized, while its old discolored cards are slowly deteriorating.

If a linguist interested in Macedonian would come to visit us from abroad, we wouldn't be able to offer him or her either a descriptive or a historical grammar, let alone an atlas or a dictionary which meets any of the modern standards. Let's not even talk of "items of luxury" such as etymological dictionaries, terminological dictionaries or the like.

Fortunately (?!), we rarely have visits from foreign colleagues because our linguists have very limited contacts within international professional circles. So much for the promotion of the Macedonian language worldwide!. Yet, we need to point out that a comprehensive linguistic analysis of the Macedonian standard language and its dialects could offer a great deal of interesting information to all interested parties, not only about Slavic and Balkan linguistic relations, but also regarding the natural language itself and the directions of its evolution. The long centuries of mainly oral commu- 
nication without any intervention from the norm have allowed the old and inherited - some even from ancient Slavic times - developmental tendencies to take further shape and evolve, while at the same time enabling the system to adapt to the multilingual Balkan environment.

The language is supposedly the most ideal incarnation of our thoughts, it is one of the essential keys to the understanding of the mechanisms of the functioning of the human brain... We can learn quite a lot, only if we allow it to develop spontaneously.

\section{LOOKING TO THE FUTURE}

Unfortunately (or maybe not...), we cannot import textbooks for learning Macedonian from Harvard or Oxford - they have to be developed here, by ourselves. For that to be achieved, we need a) societal support and b) human resources... Slowly, but surely, there is an ever growing group of young people who enjoy to read and think, and whose main interest is the Macedonian language. There is also ever growing support and understanding by the general public about the importance of the language for all of us and what our language needs and expects from us.

Our honoree should be given great credit for his contribution in the achievement of all of the above, for which I am deeply grateful to him. I hope that with his and the help of all that share his ideas and principles we shall be able to ensure that our scientific community, MASA, the universities, as well as the media are up to the task and overcome in a dignified manner all the challenges they face.

\section{SUMMARY}

This paper focuses on some of the more serious issues faced by the Macedonian language. One of them, certainly is the lack of a serious scholarly Macedonian grammar that shall be up-to-date with the development of the language which, like all other languages, is a complex adaptive system. Consequently, there is a lack of a historical grammar and modern language grammar. Another serious issue identified is the unfinished work on the dialectological dictionary and, in general, the inadequate care for dialectology. In the first part of the paper, we highlight the link between the need for greater linguistic research and the fact that this volume of the journal Contributions is dedicated to the marking of the $80^{\text {th }}$ birthday of academician Bojan Šoptrajanov, our "honorary linguist".

\section{BIBLIOGRAPHY}

[1] Б. Шоптрајанов, Белешки за јазикот на хемијата. 1. Молекула или молекул?, Глас. хем. иеехнол. Македонија, 18 (1999), 75-88.
[2] Б. Шоптрајанов, Белешки за јазикот на хемијата. 2. Правоговорот и правописот во наставата по хемија (I), Глас. хем. иехнол. Македонија, 19 (2000), 91-98.

[3] Б. Шоптрајанов, Белешки за јазикот на хемијата. 3. Правоговорот и правописот во наставата по хемија (II), Глас. хем. ишехнол. Македонија, 19 (2000), 191-196.

[4] Б. Шоптрајанов, Белешки за јазикот на хемијата. 4. За честичите, за супстанците, за радикалите, за парата и за ограниченијата, Глас. хем. иеехнол. Македонија, 19 (2000), 197203.

[5] Б. Шоптрајанов, Белешки за јазикот на хемијата. 5. За оксидите, за пероксидите, супероксидите и хидроксидите, Глас. хем. йехнол. Македонија, 20 (2001), 183-187.

[6] Б. Шоптрајанов, Белешки за јазикот на хемијата. 6. За металоидите, и за металите и семиметалите, Глас. хем. ииехнол. Македонија, 20 (2001), 189-193.

[7] Б. Шоптрајанов, Белешки за јазикот на хемијата. 7. За ураниумот и за називите на некои други елементи, Глас. хем. йехнол. Македонија, 21, (2002), 75-80.

[8] Б. Шоптрајанов, Белешки за јазикот на хемијата. 8. За величинишее и големинииее и за францускиот изговор (во македонскиот јазик) на латинските префикси и за скратените ознаки на величините и единиците, Глас. хем. иеехнол. Македонија, 21 (2002), 81-85.

[9] Б. Шоптрајанов, Белешки за јазикот на хемијата. 9. За изговорот на некои странски презимиња во наставата по хемија на македонски јазик, Глас. хем. йехнол. Македонија, 22 (2003), 61-71.

[10] Б. Шоптрајанов, Белешки за јазикот на хемијата. 10. За тетраамминбакар (II)пентацијанонитрозилферат (II)додекахидратот, Глас. хем. ииехнол. Македонија, 23 (2004), 185-191.

[11] Б. Конески, Граматика на македонскиот литературен јазик, Култура, Скопје, 1981.

[12] Б. Видоески, Дијалектите на македонскиот јазик, том 1, МАНУ, Скопје, 1998.

[13] Б. Видоески, Дијалектите на македонскиот јазик, том 2, МАНУ, Скопје, 1999.

[14] Б. Видоески, Дијалектите на македонскиот јазик, том 3, МАНУ, Скопје, 1999.

[15] Б. Видоески, Прашалник за собирање материјал за македонскиот дијалектен атлас, Институт за македонски јазик „Крсте Мисирков“, Скопје, 2000.

[16] Б. Видоески, Текстови од дијалектите на македонскиот јазик, Институт за македонски јазик „Крсте Мисирков“, Скопје, 2000. 
[17] Б. Конески, Историја на македонскиот јазик, Култура, Скопје, 1981.

[18] Петар Хр. Илиевски, Балканолошки лингвистички студии: со посебен осврт кон историскиот развој на македонскиот јазик, Институт за македонски јазик „Крсте Мисирков“, Скопје, 1988.
[19] Б. Конески, Историска фонологија на македонскиот јазик: со општ поглед врз фонолошкиот развиток на македонскиот јазик и со карта на македонските дијалекти од Божидар Видоески, МАНУ, Скопје, 2001.

\section{ЈАЗИКОТ БАРА ИСТРАЖУВАЫЕ}

\section{Зузана Тополињска}

Истражувачки центар за ареална лингвистика, Македонска академија на науките и уметностите, Скопје, Република Македонија

Во трудот се набележани некои од сериозните проблеми со кои се среќава македонскиот јазик. Еден од нив секако е недостатокот на сериозна научна граматика на македонскиот јазик којашто ќ го следи развојот на јазикот кој, како и другите јазици, е комплексен адаптивен систем. Оттаму, недостасува исйориска грамай- ика. Како сериозен проблем е наведена недовршената работа на дијалектниот речник и, воопшто, недостатната грижа за дијалектологијата. Во првиот дел од трудот се посочува врската меѓу потребата за истражување на јазикот и фактот дека овој број на списанието Прилози е посветен на одбележувањето на 80тиот роденден на академик Бојан Шоптрајанов, наш „почесен лингвист“.

Клучни зборови: македонски јазик; историјат на истражувањата на македонскиот јазик; дијалектологија; историска граматика 